\title{
EXPOSURE ASSESSMENT OF GROUNDWATER TRANSPORT OF TRITIUM FROM THE SHOAL SITE
}

\author{
Prepared by \\ Jenny Chapman, Karl Pohlmann and Roko Andricevic
}

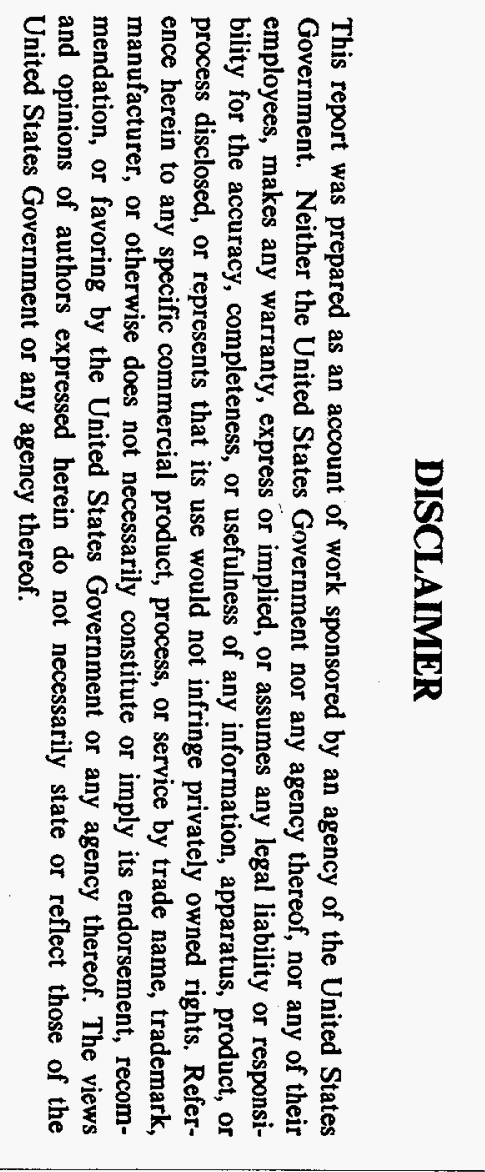

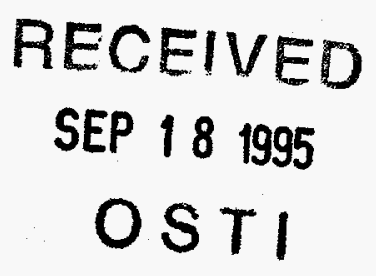

April 1995 


\section{DISCLAIMER}

Portions of this document may be illegible in electronic image products. Images are produced from the best available original document. 
This report was prepared as an account of work sponsored by the United States Government. Neither the United States nor the United States Department of Energy, nor any of their employees, makes any warranty, express or implied, or assumes any legal liability or responsibility for the accuracy, completeness or usefulness of any information, apparatus, product or process disclosed, or represents that its use would not infringe privately owned rights. Reference herein to any specific commercial product, process, or service by trade name, mark, manufacturer, or otherwise, does not necessarily constitute or imply its endorsement, recommendation, or favoring by the United States Government or any agency thereof. The views and opinions of authors expressed herein do not necessarily state or reflect those of the United States Government or any agency thereof.

This report has been reproduced directly from the best available copy.

Available to DOE and DOE contractors from the Office of Scientific and Technical Information, P.O. Box 62, Oak Ridge, TN 37831; prices available from (615) 576-8401.

Available to the public from the National Technical Information Service, U.S. Department of Commerce, 5285 Port Royal Rd., Springfield, VA 22161. 


\title{
EXPOSURE ASSESSMENT OF GROUNDWATER TRANSPORT OF TRITIUM FROM THE SHOAL SITE
}

\author{
prepared by \\ Jenny Chapman, Karl Pohlmann and Roko Andricevic \\ Water Resources Center \\ Desert Research Institute \\ University and Community College System of Nevada
}

Publication No. 45132

submitted to

Nevada Operations Office

U.S. Department of Energy

Las Vegas, Nevada

April 1995

The work upon which this report is based was supported by the U.S. Department of Energy under Contract \#DE-AC08-95NV11508. 


\section{CONTENTS}

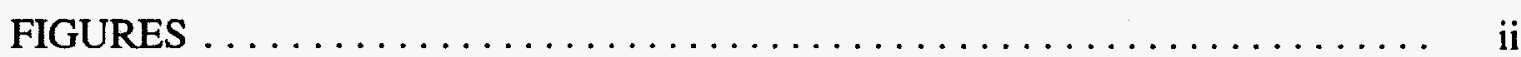

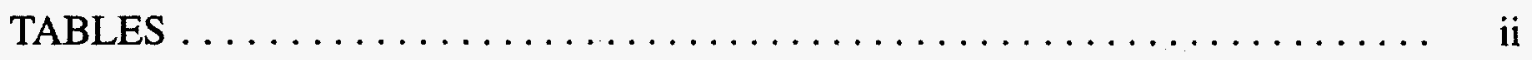

INTRODUCTION $\ldots \ldots \ldots \ldots \ldots \ldots \ldots \ldots \ldots \ldots \ldots \ldots \ldots \ldots \ldots \ldots, 1$

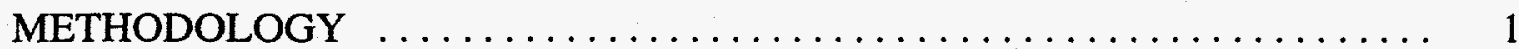

Calculation of the Expected Tritium Concentration Profile $\ldots \ldots \ldots \ldots, 2$

Calculation of the Human Health Risk .................... 3

HYDROGEOLOGIC SETTING $\ldots \ldots \ldots \ldots \ldots \ldots \ldots \ldots \ldots \ldots \ldots$

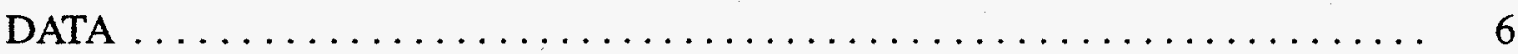

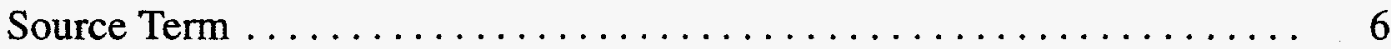

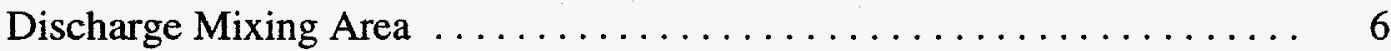

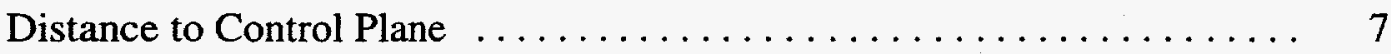

Correlation Scale $\ldots \ldots \ldots \ldots \ldots \ldots \ldots \ldots \ldots \ldots \ldots \ldots, 10$

Effective Porosity . .............................. 10

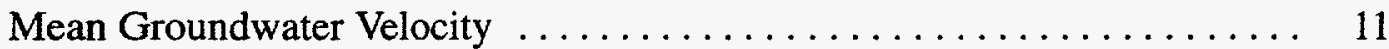

Spatial Variability in Hydraulic Conductivity $\ldots \ldots \ldots \ldots \ldots \ldots \ldots, 12$

Mean Velocity Estimation Error $\ldots \ldots \ldots \ldots \ldots \ldots \ldots \ldots \ldots, 12$

Tritium Half-Life $\ldots \ldots \ldots \ldots \ldots \ldots \ldots \ldots \ldots \ldots \ldots \ldots \ldots \ldots \ldots$

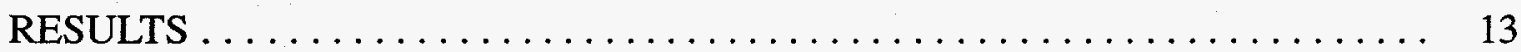

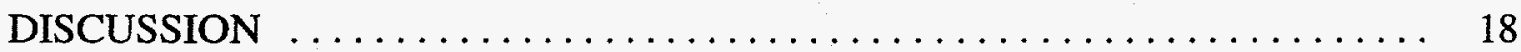

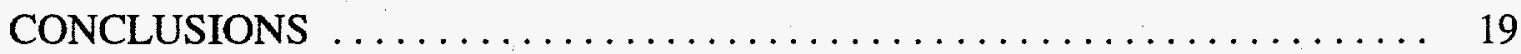

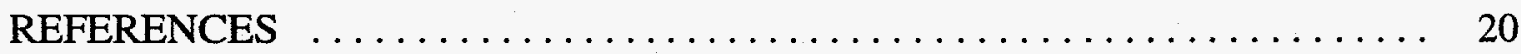

APPENDIX: Sensitivity of tritium breakthrough curves to the spatial variability in $\ln K\left(\sigma^{2} \operatorname{lnK}\right)$ and uncertainty in mean velocity for Scenarios 2, 3, and 4 ... 


\section{FIGURES}

1. Location of the Shoal underground nuclear test site in the Sand Springs Range, east of Fallon, Nevada.

2. Diagram of the four transport scenarios considered, showing the scenario number used in the report and the transport distance used in the calculations.

3. Correlation scales of hydraulic conductivity or transmissivity versus overall scale, as presented by Gelhar (1993).

4. Tritium breakthrough curves and corresponding standard deviations for Scenario 1 (4a), Scenario 2 (4b), Scenario 3 (4c), and Scenario 4(4d). .

5. Sensitivity of tritium breakthrough curves to the value for spatial variability

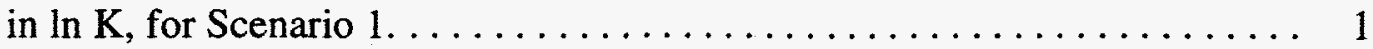

6. Sensitivity of tritium breakthrough curves to the uncertainty assumed for the mean velocity in Scenario $1 . \ldots \ldots \ldots \ldots \ldots \ldots \ldots$

7. Probability distribution function for the excess-cancer-mortality risk calculated for Scenario 1 when the spatial variability, $\sigma^{2}{ }_{\operatorname{lnK}}$, is 0.3 , and there is no uncertainty assumed for the mean groundwater velocity (Scenario la on Table 1).

TABLE

1. Health Risk Results for the Groundwater Transport Scenarios

Considered at the Shoal Site. 


\section{INTRODUCTION}

The U.S. Department of Energy (DOE) and its predecessor agencies are responsible for nuclear weapons research and development as part of the national defense program. These activities include underground nuclear testing, and a small number of such tests have been conducted at sites distant from the Nevada Test Site (NTS). An NTS site-wide Environmental Impact Statement (EIS) is being prepared in 1995 and includes the two offsite test areas in Nevada: the Shoal site and the Central Nevada Test Area. At the time of these tests, evaluations of project safety and predictions of groundwater transport of contaminants were made, and the tests were deemed safe to the public (Hazelton-Nuclear Science, 1965). These early evaluations were not considered sufficient for the EIS, so DOE decided to perform a new exposure assessment for the Shoal site. A separate evaluation of the Central Nevada Test Area was also performed and is reported by Pohlmann et al. (1995).

The Shoal site is in west-central Nevada in the Sand Springs Range, approximately $50 \mathrm{~km}$ southeast of Fallon and several kilometers south of US Highway 50. The Shoal event was part of Project Shade of the Vela Uniform Program, and was conducted to aid in the detection of nuclear detonations in active earthquake areas. The device had a yield of 12 kilotons and was detonated approximately $365 \mathrm{~m}$ below ground surface on October 26, 1963 (U.S. Atomic Energy Commission, 1964).

The basic scenario evaluated for this exposure assessment is transport of tritium from the Shoal underground nuclear test by groundwater to a receptor well where an individual drinks the contaminated water for 70 years, centered around the time of peak tritium concentration. This scenario is entirely hypothetical because, as of 1995 , there are no known occurrences of humans drinking water downgradient from the test. Four specific scenarios are analyzed because of uncertainty in flowpath direction. Two of these presume that wells are drilled at the boundary of the current DOE land withdrawal and are then used for drinking water supply. Wells do not currently exist at these locations and thus the resultant risks do not apply to any current populations; however, there are no controls to prevent such wells from being drilled in the future. The two other scenarios consider transport to the first existing wells along possible flowpaths. These wells are currently used only seasonally to water cattle, and as such, these risks also do not apply to current populations.

This assessment strives to be as accurate as possible, but the lack of data requires that significant assumptions be made about some critical parameters. Measured values were used whenever possible, but given the lack of data, calculations were performed for ranges of certain parameters. The assessment can be made more realistic with the acquisition of additional site data.

\section{METHODOLOGY}

The three-dimensional reality through which a contaminant migrates in the subsurface environment is complicated by geologic heterogeneity and tortuous connected flowpaths. In the face of incomplete data and insufficient resources, the three-dimensional reality has to be simplified and conceptualized for a particular exposure assessment. The Environmental Protection Agency (EPA) has recently promulgated a new set of exposure-assessment guidelines to replace the previous (1986) 
version (EPA, 1992a). The guidelines explicitly consider the need to estimate the distribution of exposures and discuss the need to incorporate uncertainty analysis into exposure assessment, which is also consistent with the most recent National Research Council (NRC) recommendations on exposure assessment (NRC, 1994). The EPA guidelines do not recommend specific models, but suggest that models match the objectives of the particular exposure assessment being conducted.

The technical and scheduling requirements of the EIS and scarcity of site data were inconsistent with a comprehensive exposure assessment, employing three-dimensional fate and transport modeling with characterization of geologic heterogeneity and spatial variability. Instead, a screening tool approach outlined in Daniels et al. (1993), Andricevic et al. (1994), and Andricevic and Cvetkovic (1995) was used. The employed modeling approach follows the EPA guidelines and incorporates real physical phenomena, such as instantaneous and/or slow release from the source, advection, dispersion, sorption, mass transfer, and possible uncertainty in the model parameters. The output is the expected concentration profile as a function of time (e.g., concentration breakthrough curves) at the compliance point downgradient from the source as well as the uncertainty around the expected concentration resulting from the natural geologic heterogeneity in general and from the spatially variable groundwater velocity in particular. The total exposure and corresponding uncertainty within the selected time interval (e.g., 70-year lifetime) is readily obtained from the model output and when multiplied with estimated intake and risk factors provides an estimate for individual human health risk presented by drinking groundwater downgradient from the source. The method can be considered in two distinct steps, described below: calculation of the expected tritium concentration profile and its standard deviation, and calculation of the health risk and its standard deviation.

\section{Calculation of the Expected Tritium Concentration Profile}

The solute flux method is described in detail by Andricevic and Cvetkovic (1995), while important elements of the approach can also be found in Daniels et al. (1993) and Andricevic et al. (1994). The following summary is derived from these sources, but the reader is directed to these references for a detailed treatment of the method.

The contaminant migration process is described in the solute flux method through the Lagrangian concept of motion following a particle on the pore scale. In the absence of direct information on groundwater velocities near Shoal, the mean velocity, $\bar{U}$, is calculated using Darcy's law:

$$
\bar{U}=\frac{\overline{K J}}{\overline{\bar{n}}}
$$

where $\bar{K}$ is the mean hydraulic conductivity, $\bar{J}$ is the mean hydraulic gradient, and $\bar{n}$ is the mean effective porosity. Hydrogeologic parameters such as $K$ and $n$ can be highly variable as a result of geologic heterogeneity. Numerous studies of the spatial variability of hydraulic conductivity have concluded that it is generally log-normally distributed (Freeze and Cherry, 1979; Hoeksema and Kitanidis, 1985). Thus, the natural logs of hydraulic conductivity data can be described by a normal distribution with a mean $\mu_{\ln K}$ and variance $\sigma^{2} \ln K$. The variance represents the variability of $K$ in 
space and may range from near zero for homogeneous deposits to five, or higher, for extremely variable porous media (Hoeksema and Kitanidis, 1985). Because it is distributed in space, $K$ usually has some degree of spatial correlation. The negative exponential function is often used to describe the $K$ correlation structure because it is found to correspond to $\log K$ data and is easy to use (Hoeksema and Kitanidis, 1985). The correlation length of $K, \lambda$, represents the distance at which correlation between data points ceases. The higher the value of $\lambda$, the greater the spatial continuity of $K$. When the log-normal distribution and the negative exponential covariance function are assumed, the heterogeneous, isotropic hydraulic conductivity field can be statistically characterized by three parameters: $\mu_{\ln K}, \sigma^{2} \ln K$, and $\lambda$.

If the parameters on the righthand side of the Darcy equation are log-normally distributed, then so is $\bar{U}$ and the estimate of the mean velocity is $\mu_{\ln U}=\mu_{\ln K}+\mu_{\ln J}-\mu_{\ln n}$. The variance of the estimated mean $U, \sigma^{2} \ln U$, can be calculated as the sum of the variances of the other parameters, if sufficient data are available. $\sigma^{2} \ln U$ is referred to here as the estimation error in $U$ and represents the magnitude of uncertainty in the estimate of $U$ contributed by the estimation errors of $K, J$, and $n$. The magnitude of the uncertainty in the mean velocity, $\sigma^{2} \ln U$, will depend on the number of measurements used to estimate the parameters in the Darcy equation. In the case of independent measurements, $\sigma^{2} \ln U=$ $\sigma^{2}{ }_{u} / N$, where $\sigma^{2}{ }_{u}$ is the variance in the velocity field and $N$ is the number of measurements. For spatially correlated measurements, $\sigma^{2}{ }_{u}$ is scaled by $N^{-1}[1+\bar{Q}(N-1)]$, where $\bar{\varrho}$ is an averaged spatial correlation between data points.

The solute flux method evaluates movement of a solute from the source to a plane perpendicular to the direction of flow. Aquifer heterogeneity is included and represented by the variance of $\log$-hydraulic conductivity, $\sigma^{2} \operatorname{lnK}$, and the hydraulic conductivity integral scale, $\lambda$. The combination of the spatial variability of aquifer properties and the uncertainty in the estimates of these properties causes the solute flux to be a random function described by a probability density function (pdf). The mean and variance of the solute flux are converted to the flux-averaged concentration needed for the risk calculations by dividing by the groundwater flux, $Q$. The first two moments of the flux-averaged concentration are important in determining the total risk level. The larger the magnitude of variance in the flux-averaged concentrations, the larger the maximum potential risk.

\section{Calculation of the Human Health Risk}

Details of the human health risk calculations can be found in Daniels et al. (1993) and are summarized in Andricevic et al. (1994). The following summary is derived from those sources and the reader is referred to Daniels et al. (1993) for a detailed treatment of the method.

Once the groundwater transport of tritium has been calculated, the potential excess-cancer risk for an individual consuming the contaminated groundwater can be calculated. It is assumed that groundwater at one of the four compliance points considered here is the only source of drinking water for an individual. This would require drilling new wells for two of the scenarios. Exposure of the individual is assumed to begin at birth and continue without interruption over a 70-year lifespan. The 70-year period is centered around the time of maximum annual tritium activity. The 
individual's committed effective dose is calculated by summing over the exposure period the products of the annual estimate of the activity (concentration) of tritium in the water as determined by the model (in units of $\mathrm{pCi} / \mathrm{l}$ ), the age-related annual intake of tap water, and the age-specific dose-conversion factor for each year of a 70-year lifespan.

Water intake is based on age-specific tapwater intake for both sexes and broad age categories for the western region of the U.S., quantified by Ershow and Cantor (1989). The rate of tapwater intake is assumed to be a lognormally distributed variable and the characteristics of the distribution have been described by Daniels et al. (1993). Exposure by other pathways (e.g., absorption through the skin while bathing) is not considered, and should not contribute substantially to the internal dose.

The individual's lifetime estimate of internal radiation dose is based on the dosimetric formalisms described in the International Commission on Radiological Protection (ICRP) Publication 60 (ICRP, 1991). A dose-conversion factor is used to calculate the lifetime dose from the individual's intake of tritium. To calculate the age-dependent committed effective dose per unit intake of radioactivity, each organ-specific committed equivalent dose in a given age category appearing in ICRP 56 (1990) was multiplied by its respective revised tissue-weighting factor from ICRP 60 and the products for that age category were summed. The age-category specific committed effective doses were considered to apply to each year of life identified for that age category. These annual age-specific committed effective doses are the dose-conversion factors used for estimating the lifetime dose for tritium in groundwater and agree with those calculated by Jain et al. (1992) using an analogous procedure. A tabulated summary of the factors used can be found in Daniels $e t$ al. (1993). A distribution for dose was calculated in a manner similar to that described by Daniels et al. (1993) using the distributions for activity, intake, and dose-conversion factors.

ICRP Publication 60 (ICRP, 1991), using data from numerous studies including the BEIR V report (National Research Council, 1990), computed a nominal risk value of $5 \times 10^{-2}$ per Sievert of lifetime committed effective dose for the probability of induced fatal cancer in a population of all ages following chronic low-dose exposure. This value was used by Daniels et al. (1993), and is used here. Additionally, this value is considered to be the geometric mean of a lognormally distributed variable with the characteristics of this distribution as described by Daniels et al. (1993). The geometric mean of the maximum potential excess lifetime risk of cancer mortality is computed as the product of the geometric mean of the total committed effective dose and the geometric mean of the risk factor. The method for deriving the geometric standard deviation for this distribution is described by Daniels et al. (1993). This procedure is used to derive the 90 percent confidence intervals reported here for the individual excess cancer risk.

\section{HYDROGEOLOGIC SETTING}

The Shoal event was conducted within the granitic uplift of the Sand Springs Range (Figure 1). The highland area around ground zero is a regional groundwater recharge area, with regional discharge occurring both in the Fourmile and Eightmile flats area to the west of the range and in the Humboldt Salt Marsh in Dixie Valley to the northeast of the range. The University of Nevada (1965) 


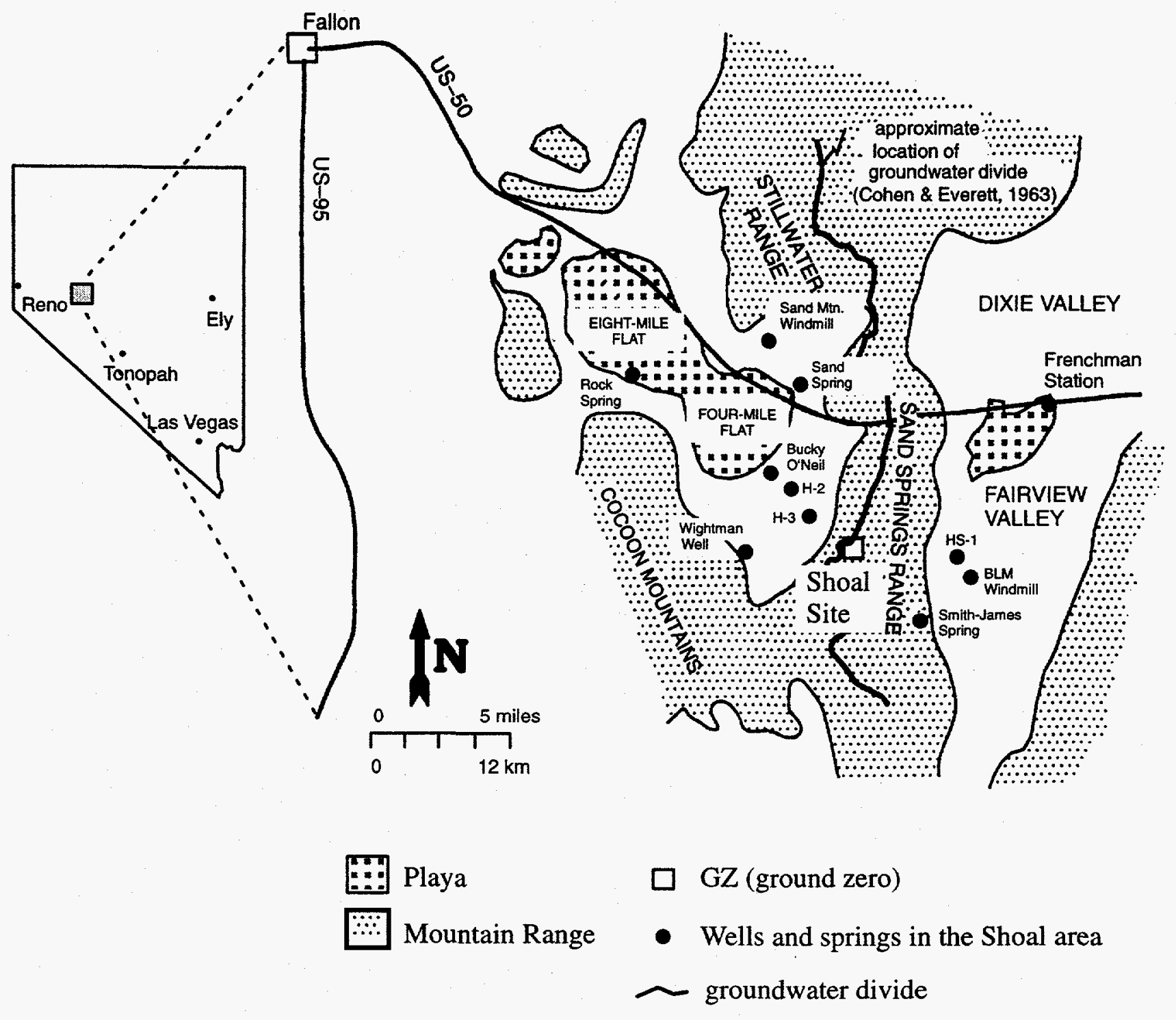

Figure 1. Location of the Shoal underground nuclear test site in the Sand Springs Range, east of Fallon, Nevada. 
analyzed hydrologic data in the Shoal area and concluded that a groundwater divide may exist northwest of the event and that the main component of lateral movement of groundwater near the shot point is southeast toward Fairview Valley. Cohen and Everett (1963) and Glancy and Katzer (1975) also identify a groundwater divide just west of the Shoal site, apparently based on a topographic divide. Though the hydraulic data suggest flow to the east from the site, hydrochemical parameters suggest flow to the west (University of Nevada, 1965), and available data are not sufficient to rule out either the east or west pathway (Chapman et al., 1994).

At the Shoal site itself, groundwater occurs within fractured, predominantly fresh, granite. Hydraulic tests conducted at the time of the Shoal event concluded that there was a range of conditions in the granite, depending on fracture geometry relative to the wells, but that overall, the transmissive capacity was low. In general, groundwater occurs about $290 \mathrm{~m}$ below ground surface in the immediate vicinity of the nuclear test, though a few high altitude springs discharging from perched zones in the granite can be found to the south. In the adjacent valleys, groundwater occurs in alluvial material eroded from the highland areas and hydraulic testing indicated much higher transmissivities. Granitic bedrock is relatively near the surface beneath a veneer of alluvium to the west of the Sand Springs Range and hydrologic data are available from one well completed in the bedrock in that area. Farther to the west, and in Fairview Valley to the east, bedrock occurs at greater depths and is not penetrated by wells. Discharge of water originating in the Sand Springs Range occurs at springs and by evapotranspiration along the edge of the salt pan in Fourmile Flat. Data from a well completed in the alluvium between the Range and the salt pan suggest that a counterflow of dense, saline water may be moving back toward the Range from the playa, driven by buoyancy forces, with fresh water moving from the Sand Springs Range confined to a thin lens at the top of the saturated zone (Chapman et al., 1994). The alluvium is much thicker in Fairview Valley and groundwater occurs in at least three separate aquifers separated by clay aquitards. No discharge to the surface occurs in Fairview Valley; rather, groundwater moves northward to discharge areas in Dixie Valley.

The only wells in the Sand Springs Range itself are associated with mining operations to the south of the Shoal site. Groundwater is used in both of the adjacent valleys for stock watering, primarily on a seasonal basis. Though there is a well at an apparent abandoned homestead in Fourmile Flat (Wightman Well) and there is a well at the location of a former store (known as Frenchman Station) in Fairview Valley, groundwater in the area is not currently used for private domestic supply.

\section{DATA}

The specific conceptual model evaluated in this exposure assessment is that of groundwater flow transporting tritium from the Shoal test through fractured granite to hypothetical receptor locations downgradient. By virtue of describing the solute flux through the Lagrangian concept of motion (following a particle on the Darcy scale), the analytical solution is actually independent of the transport medium, relying simply on the assigned transport properties. The only assumption required is that the particle trajectory not deviate significantly from the mean flow direction. This 
assumption is imbedded in the first-order approximation used to derive the arrival time moments of the moving plume (see Dagan et al., 1992). The method allows for matrix diffusion and sorption (equilibrium or non-equilibrium), but in the absence of evidence that either process is significant, they were not included in the calculations. The solute flux crossing a control plane at a given distance is calculated, and in all cases it was assumed that a well was located along that plane. The receptors are assumed to be single wells providing domestic supply, similar to current rural use in the area. The parameters used for the transport calculations are discussed in detail below. In some cases, lack of data requires that significant assumptions be made regarding the appropriate input values. Parametric uncertainty in all of the hydraulic properties is included through uncertainty in the estimate of the mean velocity.

\section{Source Term}

The tritium source term used for all scenarios is $3.0 \times 10^{16} \mathrm{pCi}$. This is based upon the value given in Table 1 of Hazelton-Nuclear Science Corp. (HNS) (1965, page 26) and is equivalent to an initial tritium concentration of $7.2 \times 10^{8} \mathrm{pCi} / 1$ in the chimney water. Their estimate is based on a calculation of tritium produced by neutron activation of lithium- 6 and a conservative estimate of the amount of lithium in the Sand Springs granite. The amount of lithium assumed by HNS ( $250 \mathrm{ppm}$ ) is ten times the concentration measured during site characterization activities. Fission-produced tritium was not considered in their total because it was small relative to the total neutron activation production of tritium.

\section{Discharge Mixing Area}

The cross-sectional area of the chimney created by the nuclear test, $5600 \mathrm{~m}^{2}$, was used as the discharge mixing area, and was the same for all scenarios. The discharge mixing area is the cross-sectional size of the contaminant plume as it passes the control plane. It is used in conjunction with the average velocity and porosity to derive the quantity of contaminated groundwater passing the plane, and thus convert the mass flux of contaminant into the concentration value needed for the health risk calculation. It is reasonable to maintain a constant source cross-sectional area during transport because the source size is small relative to the travel path lengths considered (1100 to 4000 $\mathrm{m}$, discussed in a later section) and small relative to the scale of geologic heterogeneity.

The value of $5600 \mathrm{~m}^{2}$ is the area of a cylinder with a diameter of $52 \mathrm{~m}$ and a height of $108 \mathrm{~m}$, the approximate chimney dimensions based on post-shot information contained in HNS (1965, page 22-23). Geophysical measurements in the post-shot hole drilled after the test indicated a cavity of $26 \mathrm{~m}$ and a chimney height of $108.5 \mathrm{~m}$. The force of a nuclear explosion can drive radioactivity some distance from the actual cavity through fractures, in a process referred to as prompt injection. There is evidence of prompt injection from the Shoal test from a drill hole located $135.5 \mathrm{~m}$ southeast of ground zero that was completely offset at a depth of $345 \mathrm{~m}$, suggesting that lateral fractures extended this distance, and small amounts of radioactivity were found in air below a plug in the same hole. HNS (1965) concludes that "The inference from these data is that the radioactive fracturing radius is at least 135.5 meters ( 5.2 times the cavity radius).", but goes on to note that the distribution of radionuclides in the geologic medium may not be spherical and the data from the one drill hole may 
not be representative of the average fracturing radius. Given that the vast majority of radionuclide mass remains within the chimney, the fracturing radius was neglected for determining the source size. Confining the source to the smaller chimney size is a conservative assumption because this restricts the discharge mixing area, allowing less dilution of the radionuclide mass crossing the control plane.

\section{Distance to Control Plane}

The analytic method calculates the total solute flux crossing a control plane at a given distance, and in all cases it was assumed that a single domestic supply well was located along that plane. Four scenarios were considered in the transport analysis (Figure 2) and have the following flowpath lengths: Scenario 1 - $1100 \mathrm{~m}$; Scenario 2 - $4000 \mathrm{~m}$; Scenario 3 - $2200 \mathrm{~m}$; and Scenario 4 - $3400 \mathrm{~m}$. Each of these lengths is the map distance from ground zero to an assumed receptor location, neglecting any vertical components of flow. In the Shoal hydrologic environment, such vertical flow components are likely to be significant as hydraulic head measurements in the Sand Springs Range decrease with depth, suggesting predominantly downward rather than lateral flow as characteristic of groundwater in a recharge area (Nevada Bureau of Mines et al., 1965). The resulting arcing flowpaths would have longer lengths than those assumed in these calculations.

The probable location of a groundwater divide somewhere near the source requires that both eastward and westward flowpaths be considered. Scenarios 1 and 2 are eastward flowpaths and Scenarios 3 and 4 are westward (northwest) flowpaths. Two different types of receptors were considered for each of these basic flowpath directions. Scenarios 1 and 3 consider transport to the boundary of the DOE land withdrawal. There are currently no wells located at or near this land boundary, but without any direct control beyond the four-square-mile area, future water use at these locations cannot be eliminated from consideration. The distance to the control plane for Scenario 1 is the distance due east from the source to the land withdrawal boundary. Scenario 2 evaluates eastward flow to the first current point of use in that direction, well HS-1. This well was drilled by the Atomic Energy Commission (AEC) for site characterization and water supply during Project Shoal activities and is currently used by a local rancher for seasonal stock watering. The actual distance from the source to HS- 1 is $5900 \mathrm{~m}$, but the final $1900 \mathrm{~m}$ of that is transport through alluvial material (assuming the subsurface granite/alluvium contact corresponds to the surface contact, as suggested by Plate 3 in Nevada Bureau of Mines et al., 1965). Because the analytic method employed requires a single value for mean velocity, and the hydraulic conductivity of the alluvium is much higher than that of the granite (and thus transport through the alluvium accounts for much less of the travel time), transport to the eastern point of use is approximated by transport to the inferred granite boundary at $4000 \mathrm{~m}$. This is a conservative assumption because it shortens the flowpath length.

Scenario 3 covers the distance from the source to the western boundary. Estimating from topography, groundwater flow in this direction is more likely to be northwesterly rather than due west, but the flowpath length does not differ significantly. Scenario 4 considers transport from the source to the first current water-use point west of the Shoal site, well H-3. This well was drilled by 


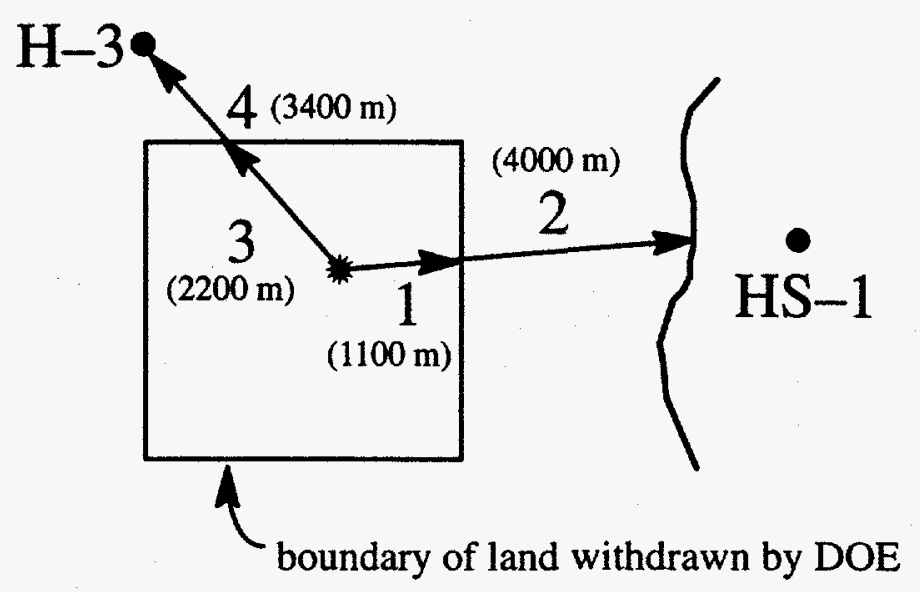

Figure 2. Diagram of the four transport scenarios considered, showing the scenario number used in the report and the transport distance used in the calculations. As described in the text, flux is actually calculated crossing a plane at the given distance. The distance to HS-1 reflects the length of the flowpath through the granite rather than the full distance to the well, as discussed in the text. The diagram is not drawn to scale.

the AEC into the granite beneath a veneer of alluvium and is currently used by a local rancher for stock watering.

\section{Correlation Scale}

The correlation scale used for each scenario is as follows: Scenario $1-110 \mathrm{~m}$, Scenario $2-400$ $\mathrm{m}$, Scenario $3-220 \mathrm{~m}$, and Scenario $4-340 \mathrm{~m}$. The correlation scale (also known as the integral scale) is the distance over which two measurements of hydraulic conductivity tend to become uncorrelated. A large value suggests a system with a high degree of spatial correlation and has the net effect of extending the path length of higher conductivity conduits. The very limited information on hydraulic properties at Shoal was not sufficient to estimate the correlation scale along the various pathways. Hoeksema and Kitanidis (1985) report a range for correlation scales of transmissivity in consolidated rock aquifers of 1400 to $44,700 \mathrm{~m}$ (mean of $17,400 \mathrm{~m}$ ), but these values refer to aquifer-wide properties and it has been shown that the correlation scale increases systematically with increasing overall scale (Gelhar, 1993). Analysis of correlation and overall scales for a number of well-characterized sites revealed a predictable relationship of the correlation scales being approximately ten percent of the overall scale (Figure 3) (Gelhar, 1993, p.293). This relationship 
was applied to the Shoal transport scenarios so that the correlation scale used was $1 / 10$ of the flowpath length.

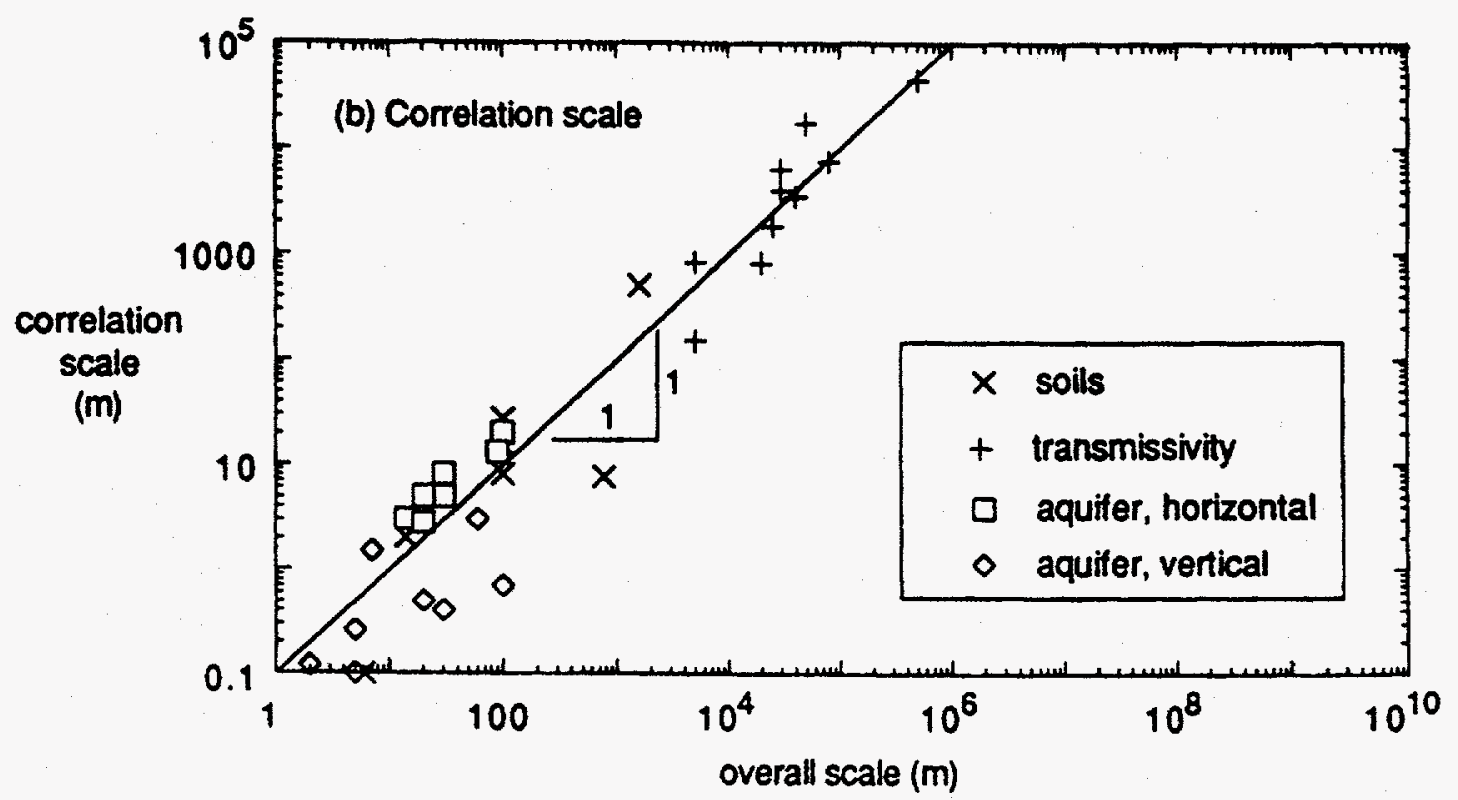

Figure 3. Correlation scales of hydraulic conductivity or transmissivity versus overall scale, as presented by Gelhar (1993). The excellent relationship is the basis for assigning a correlation scale of 10 percent to the flowpath length in this report.

\section{Effective porosity}

An effective porosity of one percent $(0.01)$ was assumed for the fractured granite. No data were available for either total or effective porosity from the unit. The total porosity of fractured rocks can vary widely, with a range of 0.2 to 0.01 reported from laboratory experiments of fractured rocks in hydrothermal systems (Norton and Knapp, 1977). A range of 0 to 0.1 has been reported in general hydrogeologic texts for the total porosity of fractured crystalline rocks (Freeze and Cherry, 1979; Domenico and Schwartz, 1990). The effective porosity is generally a small fraction of the total porosity. Measurements on two granites and a quartz diorite ranged from 0.05 to 0.00004 (Norton and Knapp, 1977, reported as "flow porosities" on their Table 1). Similarly, Freeze and Cherry (1979) state that effective porosity "...is normally very small. Values in the order of $1-0.001 \%$, or $10^{-2}-10^{-5}$ expressed as a fraction, are not unusual" (Freeze and Cherry, 1979, page 408). Two deep wells in northern Illinois found open fractures in granite even at great depth (up to $1600 \mathrm{~m}$ ), with porosity ranging from 0.0142 to 0.0215 (Fetter, 1994). The value of 0.01 used here was selected in concert with the mean hydraulic conductivity to produce a reasonable mean velocity (discussed below). The effective porosity is used with the velocity and cross-sectional area to determine the groundwater discharge across the control plane, which in turn is used to convert the contaminant flux into concentrations. The porosity is also used in the calculation of velocity, with a smaller effective 
porosity resulting in larger groundwater velocities. The uncertainty in effective porosity is incorporated in the overall uncertainty in mean velocity, discussed in a later section.

\section{Mean Groundwater Velocity}

The mean groundwater velocity used for eastward flow in the fractured granite (Scenarios 1 and 2) is $2.7 \mathrm{~m} / \mathrm{yr}$. The mean velocity used for westward flow in the granite is $5 \mathrm{~m} / \mathrm{yr}$. The difference between the two estimates is due to different hydraulic gradients in the two directions and is consistent with the difference in topographic gradient between the eastward and westward approaches to the range. For comparison, the velocity in the alluvium in Fairview Valley (east side of the Sand Springs Range) is estimated to be $99 \mathrm{~m} / \mathrm{yr}$ and the velocity in the alluvium of Fourmile Flat (west side) is estimated to be $141 \mathrm{~m} / \mathrm{yr}$. In the absence of direct measurements of flow velocities, the velocities were calculated as described below.

\section{Mean Groundwater Velocity Eastward in the Fractured Granite}

The mean velocity calculated for eastward flow through the granite, $2.7 \mathrm{~m} / \mathrm{yr}$, results from equation (1), using a hydraulic conductivity of $5 \times 10^{-8} \mathrm{~m} / \mathrm{s}$, a hydraulic gradient of 0.017 , and an effective porosity of 0.01 . The choice of porosity is discussed in an earlier section. The hydraulic conductivity is based on four measurements of transmissivity in the granite, estimates of contributing thickness for those transmissivities, and data on similar materials. The workers that performed the hydraulic tests for the three wells located within $1.6 \mathrm{~km}$ of the test site (wells PM-1, PM-3, and USBM \#1) express no confidence in the interpretation of the results because of the many differences between conditions in the granite and the idealized conditions under which the testing theory was developed. Regardless, using the transmissivities reported by the Nevada Bureau of Mines et al. (1965), and using a range of thickness derived by interpreting thickness of fractured intervals from geologic and geophysical logs of the wells, yields a range in hydraulic conductivity of $4.7 \times 10^{-8}$ to $1.1 \times 10^{-6} \mathrm{~m} / \mathrm{s}$. Data from a pump test performed in well $\mathrm{H}-3$, completed in weathered granite beneath the western alluvial fan, results in an estimate of $6.1 \times 10^{-7} \mathrm{~m} / \mathrm{s}$, assuming the entire saturated thickness of the well $(46 \mathrm{~m})$ contributed water to the test. Based on evidence derived during testing near the site, the Nevada Bureau of Mines et al. (1965, page 271) believe the transmissivity beneath the range to be less than that measured at $\mathrm{H}-3$ and summarize their findings as the granite near the site having a transmissivity less than $200 \mathrm{gpd} / \mathrm{ft}$ (reported units; $3 \times 10^{-5} \mathrm{~m}^{2} / \mathrm{s}$ ). Freeze and Cherry (1979, page 409) report that a hydraulic conductivity of $10^{-8} \mathrm{~m} / \mathrm{s}$ could represent conditions in a slightly fractured granite. $5 \times 10^{-8} \mathrm{~m} / \mathrm{s}$ was selected as consistent with the field data and literature values, and in keeping with the conclusions of the hydrogeologists responsible for the hydraulic testing that the transmissive capacity of the granite was very low. The uncertainty in mean hydraulic conductivity is incorporated in the overall uncertainty in mean velocity. This uncertainty, as well as spatial variability in the hydraulic conductivity field, is discussed below.

The hydraulic gradient of 0.017 is the estimated gradient from the test area to well HS-1 in Fairview Valley. A water table elevation of $1300 \mathrm{~m}$ above mean sea level (amsl) was selected as representative of natural conditions in the vicinity of the test. This is based on measurements of 1300 $\mathrm{m}$ amsl at hole ECH-D and PM-1. Higher water levels (up to $1355 \mathrm{~m}$ amsl) were measured in other 
wells near the test, but problems with loss of drilling fluid into the formation suggest that natural water levels in the area were impacted by drilling activities (Nevada Bureau of Mines et al., 1965). A water level of $1202 \mathrm{~m}$ amsl was used for well HS-1 and represents the static water level reported by the Nevada Bureau of Mines et al. (1965). It is assumed that the receptor is served by a single domestic supply well that causes no discernible impact on the gradient. Scenarios involving larger production wells would require assuming steeper gradients. As with porosity and hydraulic conductivity, uncertainty in the mean hydraulic gradient is incorporated in uncertainty in the mean velocity.

\section{Mean Groundwater Velocity Westward in the Fractured Granite}

The mean velocity calculated for westward flow through the granite is $5 \mathrm{~m} / \mathrm{yr}$ and results from equation (1), using a hydraulic conductivity of $5 \times 10^{-8} \mathrm{~m} / \mathrm{s}$, a hydraulic gradient of 0.032 , and an effective porosity of 0.01 . The choice of porosity and hydraulic conductivity are both discussed above. The hydraulic gradient is that from the test area to well H-3. As in the case of eastward flow, a water table elevation of $1300 \mathrm{~m}$ amsl was selected as representative of natural conditions in the vicinity of the test. A water level of $1190 \mathrm{~m}$ amsl was used for well $\mathrm{H}-3$, and is the static water level reported by the Nevada Bureau of Mines et al. (1965). Again, there is assumed to be no impact on the gradient by the receptor well.

\section{Spatial Variability in Hydraulic Conductivity}

Values of $0.3,0.6$, and 1.2 were used for the variance in the natural $\log$ of hydraulic conductivity ( $\operatorname{lnK})$. Though a mean value of hydraulic conductivity is used to obtain the mean velocity, it is known that hydraulic conductivity varies through space due to geologic variability. The variability in $\mathrm{K}$ creates flowpaths with both higher and lower mean velocities than those calculated using the mean $\mathrm{K}$, and results in spreading of a contaminant plume along the direction of flow. The spreading is noted at the control plane as early arrivals in advance of the bulk of the contaminant mass, and a "tail" of trailing arrivals behind the bulk of the mass. The early arrivals caused by spatial variability in hydraulic conductivity are particularly important when considering transport of a decaying solute such as tritium because the mass of contaminant decreases with time. A large variance allows more variation in $K$ about the mean value and thus results in a distribution of velocities that can include much faster flowpaths than the mean. A lower variance restricts the spreading about the mean.

The hydraulic conductivity data from the Shoal site were not sufficient to perform the geostatistical analysis necessary to estimate the spatial variability in $\operatorname{lnK}$. The lowest value used, 0.3 , was derived from the literature (Hoeksema and Kitanidis, 1985) and is the median value for structured variance of transmissivity found in a survey of data from consolidated rock aquifers. Hoeksema and Kitandis recommend using the median value because extreme cases tended to skew the mean away from the typical value. Though over 200 measurements were used by Hoeksema and Kitanidis (1985), data from a wide variety of consolidated rocks were used (e.g., sandstone, basalt, carbonate), none of which may adequately represent a fractured granite. The sensitivity of the 
calculations to the InK variance was examined using values two and four times the estimated median value (0.6 and 1.2 , respectively).

\section{Mean Velocity Estimation Error}

The estimation error in mean velocity accounts for uncertainty in the assigned mean velocity value due to uncertainties in mean effective porosity, mean hydraulic conductivity, and mean hydraulic gradient. The lack of data did not allow calculation of these uncertainties at the Shoal site. Instead, three values were assigned for the uncertainty in mean velocity: zero, 20 , and 40 percent of the mean velocity. The estimation error of zero represents the hypothetical case where there is no uncertainty in the estimate of mean velocity. The estimation error values of 20 and 40 percent are arbitrary values chosen out of convenience to study the sensitivity of the results to a range in estimation error. The estimation error represents one standard deviation in the distribution of error about the mean velocity. If it is assumed that the error is normally distributed, then the mean value $+/$ - two standard deviations incorporates 95 percent of the distribution. To illustrate, an estimation error of 40 percent of the mean velocity of $5 \mathrm{~m} / \mathrm{yr}$ (Scenarios 3 and 4) corresponds to a standard deviation of $2 \mathrm{~m} / \mathrm{yr}$. The range of estimation error represented by the mean $+/$ - two standard deviations is then 1 to $9 \mathrm{~m} / \mathrm{yr}$. It is important to stress that this is uncertainty in the mean velocity. The range of velocities in the flow field is incorporated through the spatial variability in hydraulic conductivity and would be expected to be much larger than the range of the mean.

The estimation error in mean velocity, like variance in $\operatorname{lnK}$, results in spreading of the contaminant plume in the direction of flow, and for the same reason: consideration of both slower and faster travel times distributed about the mean. Unlike the $\ln \mathrm{K}$ variance, this distribution of velocities is not a result of natural geologic heterogeneity; rather it is a result of our imperfect knowledge of the natural system. Even in a well-characterized aquifer, uncertainty remains about the groundwater velocity field because data must be extrapolated from one well to another. This uncertainty can be estimated from the non-correlated variability in velocity (which is usually primarily a result of uncertainty in hydraulic conductivity). In the case of Shoal, the extreme lack of data creates a situation of great uncertainty about the mean velocity and not enough data to estimate that uncertainty. This was handled by evaluating the importance of uncertainty through a sensitivity analysis that included zero, 20 and 40 percent. Both the variance in hydraulic conductivity and uncertainty in velocity can be determined by field measurements and the uncertainty can be reduced during that process.

\section{Tritium Half-Life}

A half-life of 12.4 years was used for the decay rate of tritium in the calculations. The decay behavior is important to the resultant solute flux because that portion of the mass traveling at slower velocities is removed by decay before reaching the control plane. This results in the elimination of long travel times from the risk calculation and a comparative emphasis on the portion of the mass subject to early arrival.

\section{RESULTS}


Of the four transport pathways considered, Scenario 1, flow to the eastern site boundary, experiences the earliest passage of the peak tritium concentration, and the highest concentrations (Figure 4). Using the base case parameters (variance in $\operatorname{lnK}$ of 0.3 and no uncertainty in mean velocity), the peak concentration of $280 \mathrm{pCi} /$ passes the eastern boundary 206 years after the nuclear test. Peak concentrations under Scenario 3 (to the western boundary) arrive almost one half-life later, at 216 years, and are lower $(57 \mathrm{pCi} / 1)$ as a result of decay and spreading along the longer flowpath. The peak arrival at the first existing western well $(\mathrm{H}-3)$ occurs next, at 278 years, at a concentration of $0.1 \mathrm{pCi} / 1$. The combination of longest flowpath and slower mean velocity delays the peak arrival at the first existing eastern well, HS-1, until 410 years after the test, at an undetectable concentration of $3 \times 10^{-8} \mathrm{pCi} / 1$.

If a higher correlated variance in the hydraulic conductivity field is assumed, the peak concentrations rise dramatically and arrive earlier (Figure 5). Considering Scenario 1, peak concentrations increase from $280 \mathrm{pCi} / /$ when $\sigma^{2}{ }_{\operatorname{lnK}}$ is assumed to be 0.3 , to $4700 \mathrm{pCi} / 1$ when $\sigma^{2} \operatorname{lnK}$ is doubled to 0.6 , and to $85,000 \mathrm{pCi} / 1$ when $\sigma^{2} \operatorname{lnK}$ is 1.2 . The effect of including a wider range in hydraulic conductivity is magnified by radioactive decay because the portion traveling along the more rapid flowpaths arrives not only earlier, but at higher concentration due to the shorter decay time. Including uncertainty in mean velocity in the calculations also increases peak concentrations while shortening the arrival time of that peak (Figure 6). Again considering Scenario 1, a 20 percent uncertainty in mean velocity raises the peak concentration to $2600 \mathrm{pCi} / 1$, and 40 percent uncertainty raises it to $83,000 \mathrm{pCi} /$. The earliest arrival times and highest concentrations are calculated for each scenario using a combination of high uncertainty in mean velocity ( 40 percent) and large spatial variability in the hydraulic conductivity field (1.2) (Figure 4). With those parameters, Scenario 1 has a peak concentration of $720,000 \mathrm{pCi} /$ arriving 71 years after the test.

The standard deviation for the solute flux is at least an order of magnitude larger than the estimated mean flux (Figure 4). This is partially due to spatial variability in the velocity field and uncertainty in the estimate of mean velocity (incorporating uncertainty in the mean effective porosity, mean hydraulic conductivity, and mean hydraulic gradient), and partially due to the evaluation method which represents the upper bound by not accounting for pore-scale dispersion. As noted by Andricevic and Cvetkovic (1995), the peak value of the standard deviation is shifted toward the origin relative to the mean solute flux curve because the uncertainty is greatest when the solute flux is changing rapidly. The magnitude of the solute flux standard deviation is an important factor in calculating the uncertainty in the risk evaluation.

The human health risks associated with the various scenarios also vary tremendously depending on the values of variance in hydraulic conductivity and uncertainty in mean velocity (Table 1). The 90 percent risk confidence interval is picked between the five and 95 percent risk levels on the cumulative risk function (Figure 7). The 90 percent excess-cancer-mortality-risk confidence intervals for the initial case ( $\sigma^{2} \mathrm{lnK}$ of 0.3 and no uncertainty) of each scenario are all below the $10^{-6}$ goal for excess risk from exposure to contaminants in environmental media established by the U.S. Environmental Protection Agency (U.S. EPA, 1990). However, including greater variance in hydraulic conductivity and uncertainty in mean velocity raises many of the 

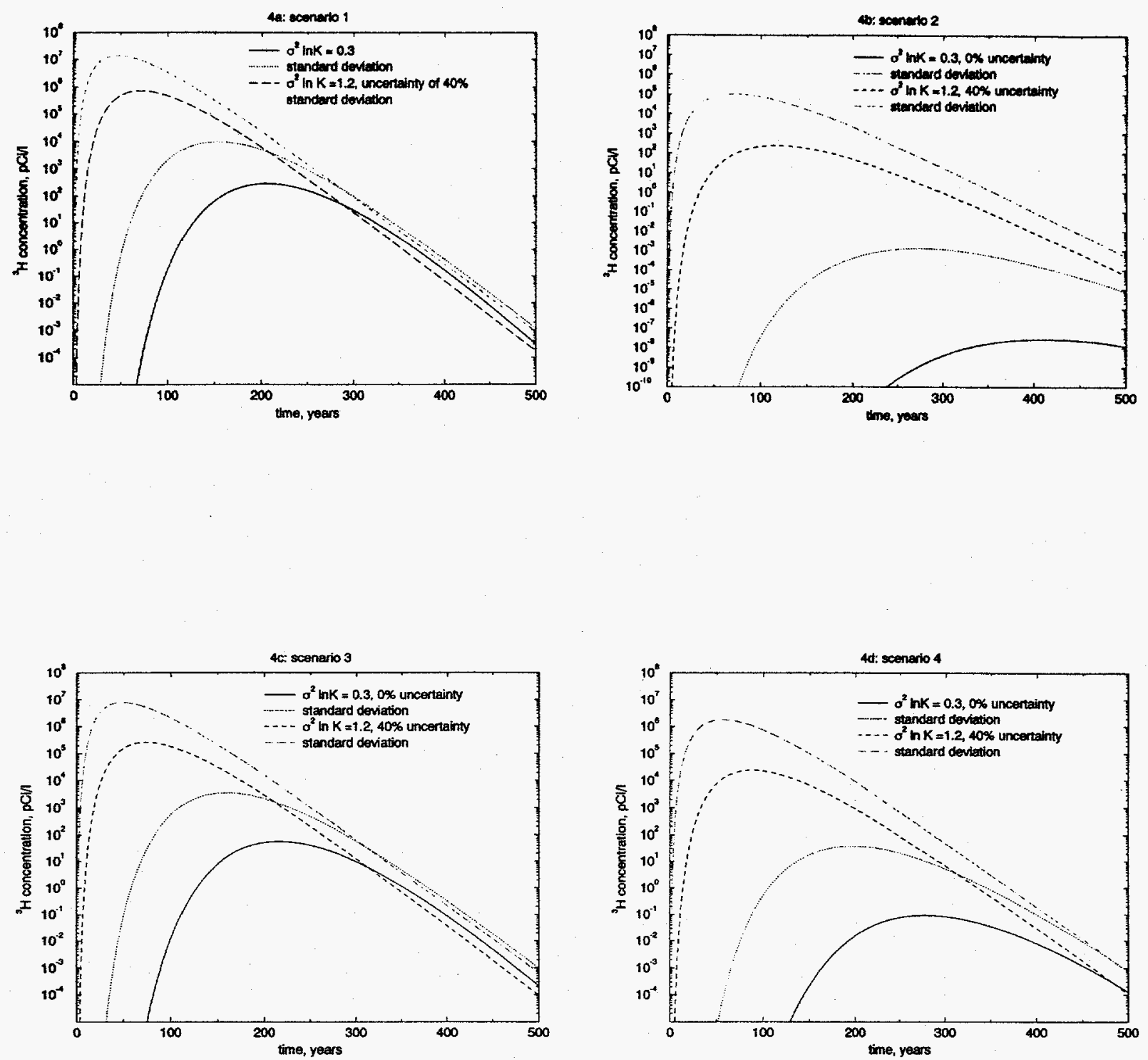

Figure 4. Tritium breakthrough curves and corresponding standard deviations for Scenario 1 (4a), Scenario 2 (4b), Scenario 3 (4c), and Scenario 4 (4d). The two bounding cases for each scenario are shown: the case of $\sigma^{2} \ln K=0.3$ with no uncertainty in mean velocity (scenarios $1 \mathrm{a}, 2 \mathrm{a}, 3 \mathrm{a}$, and $4 \mathrm{a}$ on Table 1 ), and the case of $\sigma^{2} \operatorname{lnK}=1.2$ with $40 \%$ uncertainty in mean velocity (scenarios $1 \mathrm{f}, 2 \mathrm{f}, 3 \mathrm{f}$, and $4 \mathrm{f}$ on Table 1 ). The earliest breakthrough and highest concentration between all the scenarios occurs with scenario 1 , while scenario 2 has the lowest concentration. 


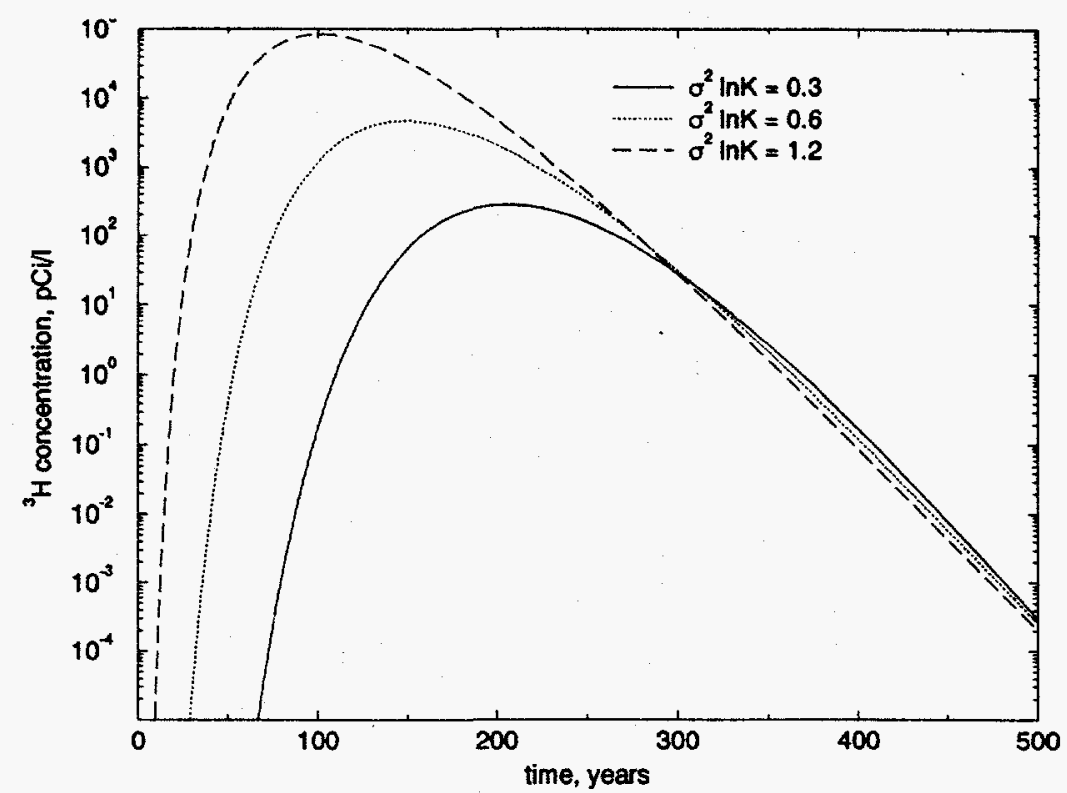

Figure 5. Sensitivity of tritium breakthrough curves to the value for spatial variability in $\operatorname{lnK}$, for Scenario 1 (Scenarios 1a, 1d, and le on Table 1). Increasing $\sigma^{2}$ lnK from 0.3 to 1.2 shortens the arrival time of the peak flux and dramatically increases the peak concentration. The sensitivity to $\sigma^{2} \operatorname{lnK}$ for the other scenarios can be found in the appendix.

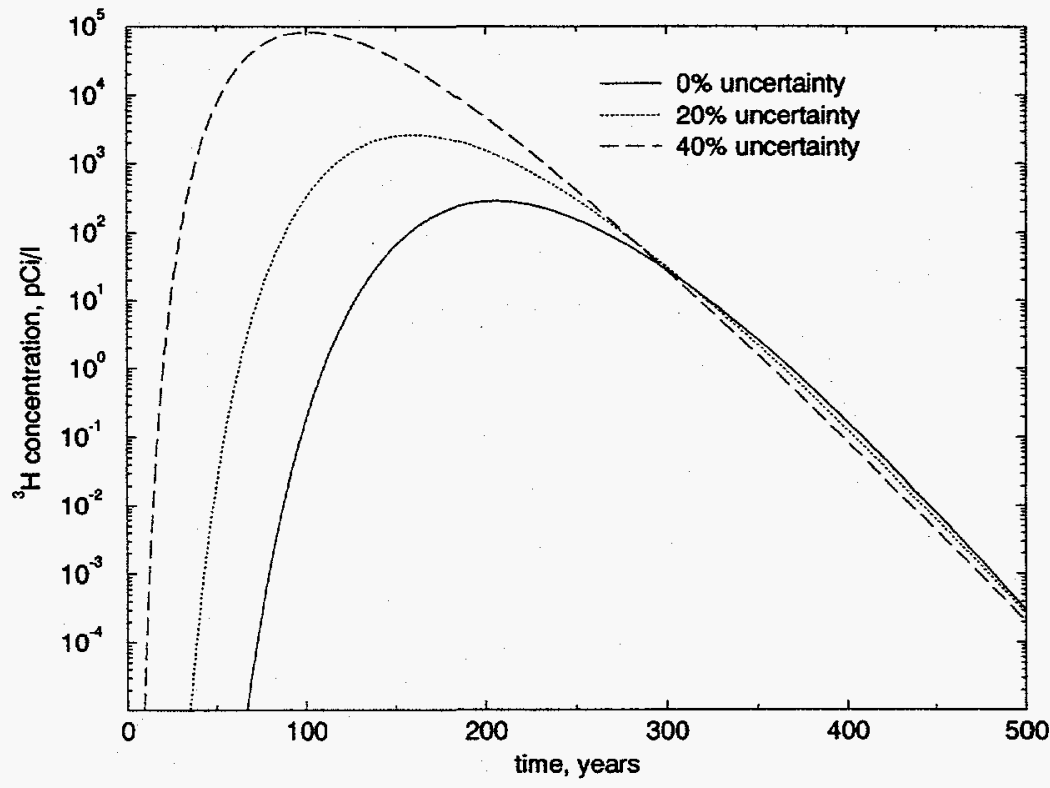

Figure 6. Sensitivity of tritium breakthrough curves to the uncertainty assumed for the mean velocity in Scenario 1 (Scenarios 1a, 1b, and $1 \mathrm{c}$ on Table 1). Increasing the uncertainty from zero to 40 percent shortens the arrival time and dramatically increases the peak concentration. The sensitivity to uncertainty in mean velocity for the other scenarios can be found in the appendix. 
calculations above the $10^{-6}$ goal, particularly when the control plane is considered to be the site boundary. The highest risks are associated with the case of high spatial variability (1.2) combined

$$
\sigma_{\mathrm{U}}^{2} \quad \sigma_{\operatorname{lnK}}^{2}
$$

TABLE 1. HEALTH RISK RESULTS FOR THE GROUNDWATER TRANSPORT SCENARIOS CONSIDERED AT THE SHOAL SITE. The risk numbers bound the excess-cancer-mortality risk between the five and 95 percent levels on the cumulative risk function, as shown on Figure 7.

\begin{tabular}{cccccccc}
\hline \hline Scenario & $\overline{\mathrm{U}}, \mathrm{m} / \mathrm{yr}$ & & & $\lambda$ & \multicolumn{3}{c}{$90 \%$ Risk Confidence Interval } \\
\hline 1a & 2.7 & 0 & 0.3 & $1 / 10 \mathrm{~L}$ & $2 \times 10^{-10}$ & to & $8 \times 10^{-7}$ \\
1b & 2.7 & $20 \%$ & 0.3 & $1 / 10 \mathrm{~L}$ & $2 \times 10^{-9}$ & to & $7 \times 10^{-6}$ \\
$1 \mathrm{c}$ & 2.7 & $40 \%$ & 0.3 & $1 / 10 \mathrm{~L}$ & $6 \times 10^{-8}$ & to & $2 \times 10^{-4}$ \\
1d & 2.7 & 0 & 0.6 & $1 / 10 \mathrm{~L}$ & $3 \times 10^{-9}$ & to & $1 \times 10^{-5}$ \\
$1 \mathrm{e}$ & 2.7 & 0 & 1.2 & $1 / 10 \mathrm{~L}$ & $6 \times 10^{-8}$ & to & $2 \times 10^{-4}$ \\
1f & 2.7 & $40 \%$ & 1.2 & $1 / 10 \mathrm{~L}$ & $7 \times 10^{-7}$ & to & $2 \times 10^{-3}$ \\
$2 \mathrm{a}$ & 2.7 & 0 & 0.3 & $1 / 10 \mathrm{~L}$ & $4 \times 10^{-24}$ & to & $4 \times 10^{-18}$ \\
$2 \mathrm{~b}$ & 2.7 & $20 \%$ & 0.3 & $1 / 10 \mathrm{~L}$ & $3 \times 10^{-20}$ & to & $2 \times 10^{-14}$ \\
$2 \mathrm{c}$ & 2.7 & $40 \%$ & 0.3 & $1 / 10 \mathrm{~L}$ & $5 \times 10^{-15}$ & to & $7 \times 10^{-10}$ \\
$2 \mathrm{~d}$ & 2.7 & 0 & 0.6 & $1 / 10 \mathrm{~L}$ & $3 \times 10^{-19}$ & to & $1 \times 10^{-13}$ \\
$2 \mathrm{e}$ & 2.7 & 0 & 1.2 & $1 / 10 \mathrm{~L}$ & $5 \times 10^{-15}$ & to & $8 \times 10^{-10}$ \\
$2 \mathrm{f}$ & 2.7 & $40 \%$ & 1.2 & $1 / 10 \mathrm{~L}$ & $4 \times 10^{-12}$ & to & $2 \times 10^{-7}$ \\
$3 \mathrm{a}$ & 5 & 0 & 0.3 & $1 / 10 \mathrm{~L}$ & $2 \times 10^{-11}$ & to & $1 \times 10^{-7}$ \\
$3 \mathrm{~b}$ & 5 & $20 \%$ & 0.3 & $1 / 10 \mathrm{~L}$ & $2 \times 10^{-10}$ & to & $1 \times 10^{-6}$ \\
$3 \mathrm{c}$ & 5 & $40 \%$ & 0.3 & $1 / 10 \mathrm{~L}$ & $9 \times 10^{-9}$ & to & $6 \times 10^{-5}$ \\
$3 \mathrm{~d}$ & 5 & 0 & 0.6 & $1 / 10 \mathrm{~L}$ & $3 \times 10^{-10}$ & to & $3 \times 10^{-6}$ \\
$3 \mathrm{e}$ & 5 & 0 & 1.2 & $1 / 10 \mathrm{~L}$ & $9 \times 10^{-9}$ & to & $6 \times 10^{-5}$ \\
$3 \mathrm{f}$ & 5 & $40 \%$ & 1.2 & $1 / 10 \mathrm{~L}$ & $1 \times 10^{-7}$ & to & $6 \times 10^{-4}$ \\
$4 \mathrm{a}$ & 5 & 0 & 0.3 & $1 / 10 \mathrm{~L}$ & $4 \times 10^{-15}$ & to & $1 \times 10^{-10}$ \\
$4 \mathrm{~b}$ & 5 & $20 \%$ & 0.3 & $1 / 10 \mathrm{~L}$ & $2 \times 10^{-13}$ & to & $6 \times 10^{-9}$ \\
$4 \mathrm{c}$ & 5 & $40 \%$ & 0.3 & $1 / 10 \mathrm{~L}$ & $7 \times 10^{-11}$ & to & $2 \times 10^{-6}$ \\
$4 \mathrm{~d}$ & 5 & 0 & 0.6 & $1 / 10 \mathrm{~L}$ & $5 \times 10^{-13}$ & to & $2 \times 10^{-8}$ \\
$4 \mathrm{e}$ & 5 & 0 & 1.2 & $1 / 10 \mathrm{~L}$ & $8 \times 10^{-11}$ & to & $2 \times 10^{-6}$ \\
$4 \mathrm{f}$ & 5 & $40 \%$ & 1.2 & $1 / 10 \mathrm{~L}$ & $3 \times 10^{-9}$ & to & $4 \times 10^{-5}$ \\
\hline \hline
\end{tabular}

with high uncertainty (40 percent), which causes risk in excess of $10^{-6}$ at the 95 percent upper confidence level for every scenario except Scenario 2 . None of the sensitivity runs for flow to HS-1 (Scenario 2) resulted in risk above $10^{-6}$; but for well $\mathrm{H}-3$ (Scenario 4 ), Cases $4 \mathrm{c}$ and $4 \mathrm{f}$, with 40 percent uncertainty in mean velocity and $\sigma^{2} \operatorname{lnK}$ of 0.3 and 1.2 , and Case $4 \mathrm{e}$, with zero uncertainty and a $\sigma^{2} \operatorname{lnK}$ of 1.2 , gave risks exceeding $10^{-6}$ at the 95 percent upper confidence limit $\left(2 \times 10^{-6}, 4\right.$ $\mathrm{x} 10^{-5}$, and $2 \times 10^{-6}$, respectively).

\section{DISCUSSION}

The large range in health risk values computed for groundwater transport of tritium from the Shoal site is a result of lack of hydrogeologic knowledge about the site. The data uncertainty is discussed in the description of each parameter earlier in the report; but the impact of these uncertainties on the calculated risks warrants additional discussion here.

Within each scenario, there is great variation in the risks reported in Table 1 . This variation is a direct result of the range of values considered for spatial variability in the hydraulic conductivity field and uncertainty in mean velocity. Both of these parameters can be determined from field 


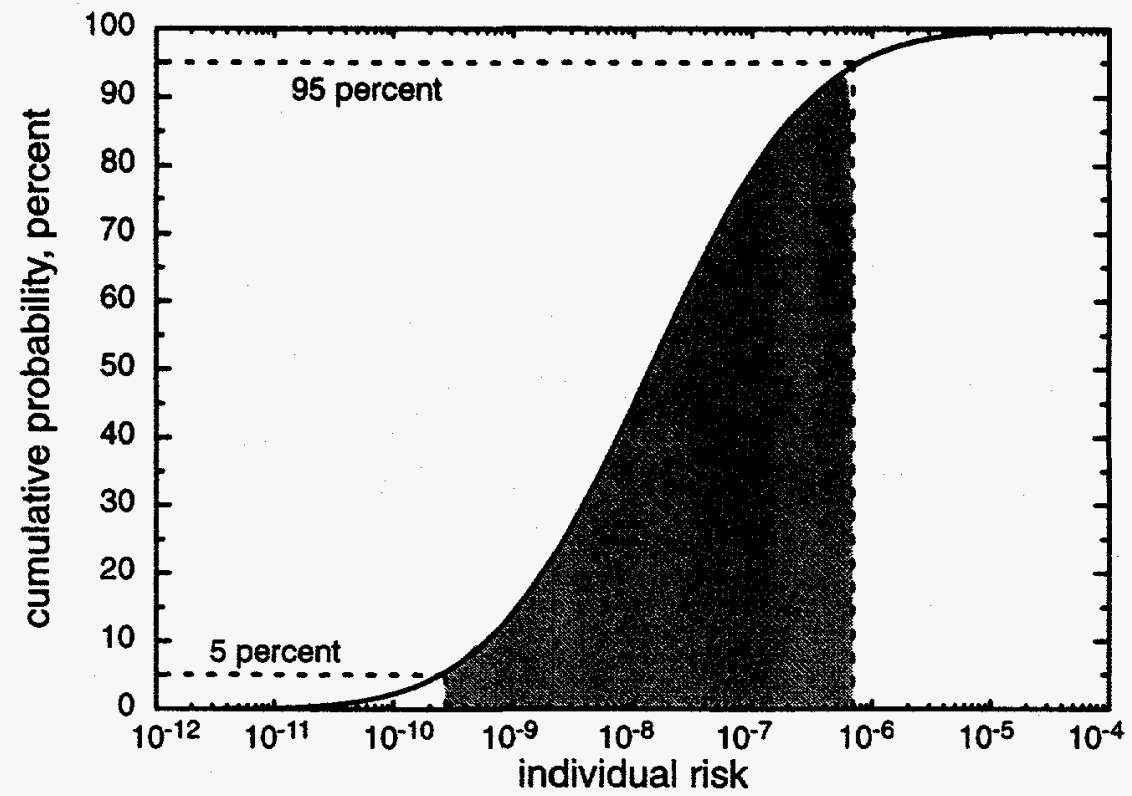

Figure 7. Probability distribution function for the excess-cancer-mortality risk calculated for Scenario 1 when the spatial variability, $\sigma^{2} \operatorname{lnK}$, is 0.3 , and there is no uncertainty assumed for the mean groundwater velocity (Scenario 1a on Table 1). The 90 percent confidence intervals reported in Table 1 are derived from the five and 95 percent probability levels, as shown.

measurements so that the range of each could be significantly reduced with additional site data. The value of uncertainty in mean velocity can actually be reduced, and theoretically eliminated, as more velocity data are developed, reducing calculated spreading of the tritium plume. Traditionally, uncertainty in calculated groundwater velocities results primarily from uncertainty in the value of hydraulic conductivity, because hydraulic conductivity usually ranges over more orders of magnitude than plausible values of either the hydraulic gradient or effective porosity. In the case of Shoal, however, uncertainty in effective porosity also contributes significantly to the overall uncertainty in velocity because effective porosity in fractured rocks is poorly known and estimates range over orders of magnitude. In addition, very steep gradients were reported close to the site and, though assumed here to be due to drilling activities, need to be investigated further. Spatial variability in hydraulic conductivity is based on geologic heterogeneity, and as such cannot be eliminated nor necessarily reduced with new data, but determining a value based on site data rather than values reported in the literature will reduce the range in risk that results from the factor of four variation considered in our calculations ( 0.3 to 1.2$)$. It is worth noting that water samples are collected annually from HS- 1 and $\mathrm{H}-3$ and analyzed for tritium as part of the Long-Term Hydrologic Monitoring Program (U.S. EPA, 1992b). Though no tritium has been detected at either well, the monitoring data cannot be used to eliminate the parameter combinations resulting in rapid flow because the contaminant plume is small in size and could easily miss either well if not directly on the flowpath.

Though not addressed through sensitivity analysis, there are additional factors important to interpreting the health risks from hydrologic transport at Shoal. These are the correlation scale, discharge mixing area, and source term. As site hydrologic data are acquired to address the velocity 
uncertainty and spatial variability, data will also be available to calculate the correlation scale for the site. Though the approach taken in this work of using 0.1 of the domain is well supported by existing literature (Gelhar, 1993), the calculations are sensitive to this parameter and a value based on site data is needed. The discharge mixing area is another critical factor for the health risk calculation because it is used to convert the mass of contaminant to the concentration used as an input dose. Using the size of the test cavity is conservative and it is not plausible to consider any smaller area, but larger mixing areas are entirely possible and, if justified based on site data, would reduce calculated concentrations and thus risks. Finally, the calculation of the tritium source term performed by Hazleton-Nuclear Science (1965) included a conservative factor of ten in the amount of lithium in the granite. If better calculations of the tritium source become available, ideally supported by measurements after the test, the risks should be recalculated. Additionally, other radionuclides are present in the source and may need to be considered.

\section{CONCLUSIONS}

This exposure assessment, while unable to narrowly constrain the human health risk presented by groundwater transport from the Shoal underground nuclear test, presents a range of possible excess-cancer-mortality risk that could exist at four different points around the site. These points correspond to the boundary of the land under DOE control (where no wells currently exist) and the closest existing well, in both the east and west directions because the location of the site with respect to a groundwater divide is unknown. The range in excess risk is within the EPA goal for excess risk due to environmental contaminants $\left(10^{-6}\right)$ at the closest existing well east of the site, HS-1, but exceeds the EPA goal for cases of high spatial variability in hydraulic transport properties and/or high uncertainty in mean velocity for the remaining three scenarios. Calculations considering less spatial variability and/or less uncertainty result in agreement with the EPA goal for all of the scenarios.

The range in risk values can be reduced with the addition of data from the site; most importantly, by determination of the direction of groundwater flow from the nuclear cavity and measurements of groundwater velocity and its spatial statistical properties (variance and correlation scale). Without more confidence in these factors, the exposure assessment reported here should be considered preliminary in nature and most useful for guiding site characterization efforts and establishing relative risk compared to other offsite underground nuclear testing locations.

\section{REFERENCES}

Andricevic, R. and V. Cvetkovic, 1995, in review, Evaluation of risk from contaminants migrating by groundwater. Submitted to Water Resources Research.

Andricevic, R., J.I. Daniels and R.L. Jacobson, 1994, Radionuclide migration using a travel time transport approach and its application in risk analysis. Journal of Hydrology, V. 163, pp.125-145.

Borg, I.Y., R. Stone, H.B. Levy and L.D. Ramspott, 1976, Information Pertinent to the Migration of Radionuclides in Ground Water at the Nevada Test Site, Part 1: Review and Analysis of Existing Information. Lawrence Livermore National Laboratory Report UCRL-52078 Pt. 1, 216 p. 
Chapman, J.B., T. Mihevc and A. McKay, 1994, Groundwater Flow Near the Shoal Site, Sand Springs Range, Nevada: Influence of Density-Driven Flow. Desert Research Institute, Water Resources Center Report No. 45130, DOE/NV/10845-51, 24 p.

Cohen, P. and D.E. Everett, 1963, A Brief Appraisal of the Ground-Water Hydrology of the Dixie-Fairview Area, Nevada, State of Nevada Department of Conservation and Natural Resources, Ground-Water Resources-Reconnaissance Series Report 23, 40 p.

Dagan, G., V. Cvetkovic, and A. Shapiro, 1992, A solute flux approach to transport in heterogeneous formations 1. The general approach. Water Resources Research, V. 28, No. 5, pp. 1369-1376.

Daniels, J.I., R. Andricevic, L.R. Anspaugh and R.L. Jacobson, 1993, Risk-based screening analysis of ground water contaminated by radionuclides introduced at the Nevada Test Site (NTS), Lawrence Livermore National Laboratory Report, UCRL-ID-112789, 29 p.

Domenico, P.A. and F.W. Schwartz, 1990, Physical and Chemical Hydrogeology. John Wiley and Sons, $824 \mathrm{p}$.

Ershow, A.G. and K.P. Cantor, 1989, Total Water and Tapwater Intake in the United States: Population-Based Estimates of Quantities and Sources. Federation of American Societies for Experimental Biology, Bethesda, MD, National Cancer Institute Order \#263-MD-810264.

Fetter, C.W., 1994, Applied Hydrogeology (3rd Edition). Macmillan College Publishing Co., 691 p.

Freeze, R.A. and J.A. Cherry, 1979, Groundwater. Prentice-Hall, Inc., Englewood Cliffs, New Jersey, $604 \mathrm{p}$.

Gelhar, L.W., 1993, Stochastic Subsurface Hydrology. Prentice Hall, Englewood Cliffs, New Jersey, $390 \mathrm{p}$.

Glancy, P.A. and T.L. Katzer, 1975, Water-Resources Appraisal of the Carson River Basin, Western Nevada: State of Nevada Department of Conservation and Natural Resources, Ground-Water Resources-Reconnaissance Series Report 59, 126 pp.

Glasstone, S. and P.J. Dolan, 1977, The Effects of Nuclear Weapons, 3rd Edition. U.S. Dept. of Defense and U.S. Dept. of Energy, 653 p.

Hazelton-Nuclear Science Corporation, 1965, Post-Shot Hydrologic Safety. U.S. Atomic Energy Commission Report VUF-1014, 50 p.

Hoeksema, R.J. and P.K.Kitanidis, 1985, Analysis of spatial structure of properties of selected aquifers. Water Resources Research, Vol. 21, pp. 563-572.

Hoffman, D.C., R. Stone and W.W. Dudley, Jr., 1977, Radioactivity in the Underground Environment of the Cambric Nuclear Explosion at the Nevada Test Site. Los Alamos Scientific Laboratory Informal Report LA-6877-MS. 89 p. 
International Commission on Radiological Protection (ICRP), 1991, ICRP Publication 60: 1990 Recommendations of the International Commission on Radiological Protection. Pergamon Press, New York, NY, Vol. 21, No. 1-3.

International Commission on Radiological Protection (ICRP), 1990, ICRP Publication 56: Age-Dependent Doses to Members of the Public from Intake of Radionuclides: Part I. Pergamon Press, New York, NY, Vol. 20, No. 2.

Jain, S.C., A. Nagaratnam, A.R. Reddy, M.M. Gupta and S.C. Mehtall, 1992, Revised Age-Dependent Doses to Members of the Public from Intake of Radionuclides Using the New Tissue Weighting Factors. Radiat. Prot. Dosim., Vol. 40, pp. 111-115.

National Research Council, 1994, Science and Judgement in Risk Assessment. National Academy Press, Washington, D.C., 651 p.

National Research Council, 1990, Health Effects of Exposure to Low Levels of Ionizing Radiation, BEIR V. National Academy Press, Washington, DC.

Norton, D. and R. Knapp, 1977, Transport phenomena in hydrothermal systems: the nature of porosity. American Journal of Science, Vol. 277, pp.913-936.

Pohlmann, K., J. Chapman, and R. Andricevic, 1995, Exposure Assessment of Groundwater Transport of Tritium From the Central Nevada Test Area. Desert Research Institute, Water Resources Center Publication \#45133, 21 p.

Reynolds Electrical and Engineering Co., Inc., Special Projects Section, 1993a, Hydrogeologic Data for Science Trench Boreholes at the Area 5 Radioactive Waste Management Site, Nevada Test Site, Nevada. Report prepared for the U.S. Dept. of Energy, Nevada Operations Office, variable paging.

Reynolds Electrical and Engineering Co., Inc., Special Projects Section, 1993b, Site Characterization and Monitoring Data From Area 5 Pilot Wells, Nevada Test Site, Nevada. Report prepared for the U.S. Dept. of Energy, Nevada Operations Office, variable paging.

U.S. Atomic Energy Agency, 1964, Project Manager's Report, Project Shoal. Nevada Operations Office Report NVO-11, 82 p. + appendices.

U.S. Environmental Protection Agency, 1990, National Oil and Hazardous Substances Pollution Contingency Plan, Final Rule (40 CFR Part 300). Federal Register V. 55, No. 46, pp.8666-8865.

U.S. Environmental Protection Agency, 1992a, Guidelines for Exposure Assessment. Federal Register V. 57, pp. 22888-22938.

U.S. Environmental Protection Agency, 1992b, Offsite Environmental Monitoring Report: Radiation Monitoring Around United States Nuclear Test Areas, Calendar Year 1991. EPA 600/R-93/141, 232 p. 
University of Nevada, 1965, Geological, Geophysical, Chemical and Hydrological Investigations of the Sand Springs Range, Fairview Valley and Fourmile Flat, Churchill County, Nevada. Prepared for the U.S. Atomic Energy Commission, Report VUF-1001, $369 \mathrm{p}$. 


\section{APPENDIX}

SENSITIVITY OF TRITIUM BREAKTHROUGH CURVES TO THE SPATIAL VARIABILITY IN $\operatorname{lnK}\left(\sigma^{2} \operatorname{lnK}\right)$ AND UNCERTAINTY IN MEAN VELOCITY FOR SCENARIOS 2, 3, AND 4 
(a)

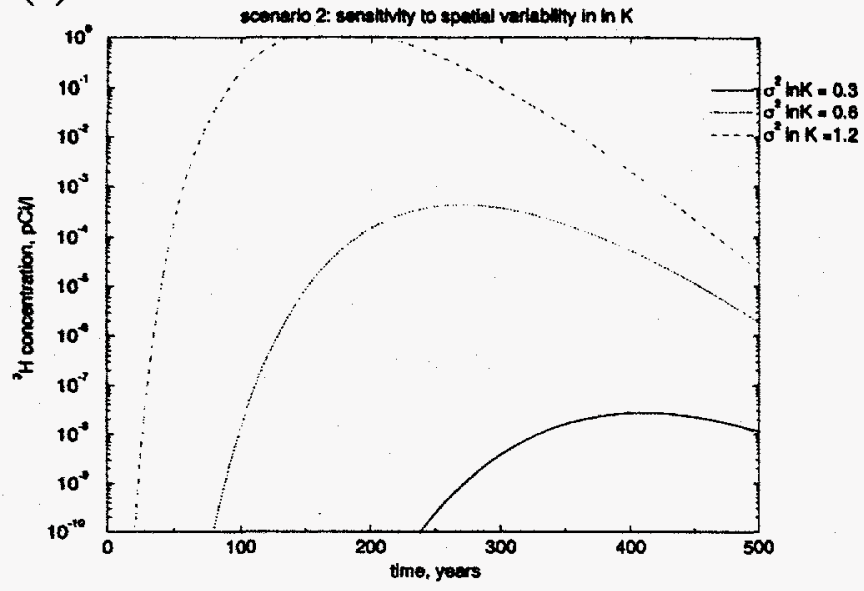

(c)

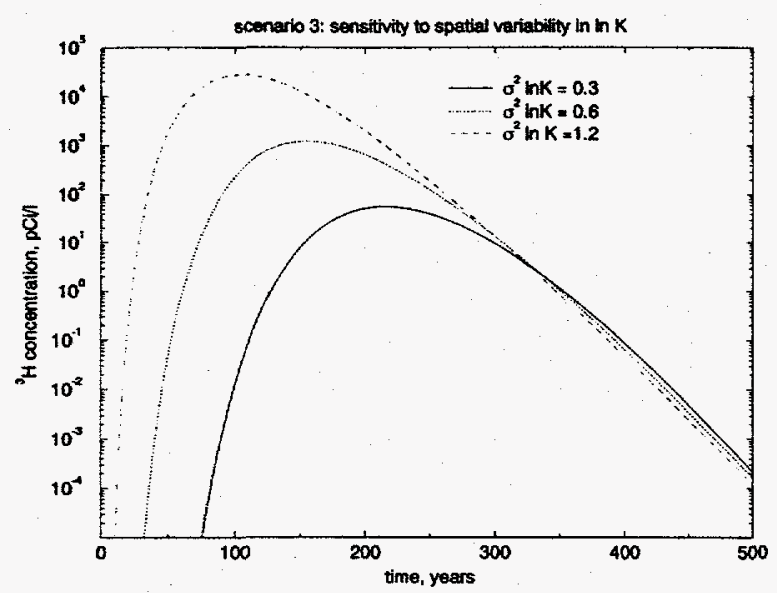

(e)

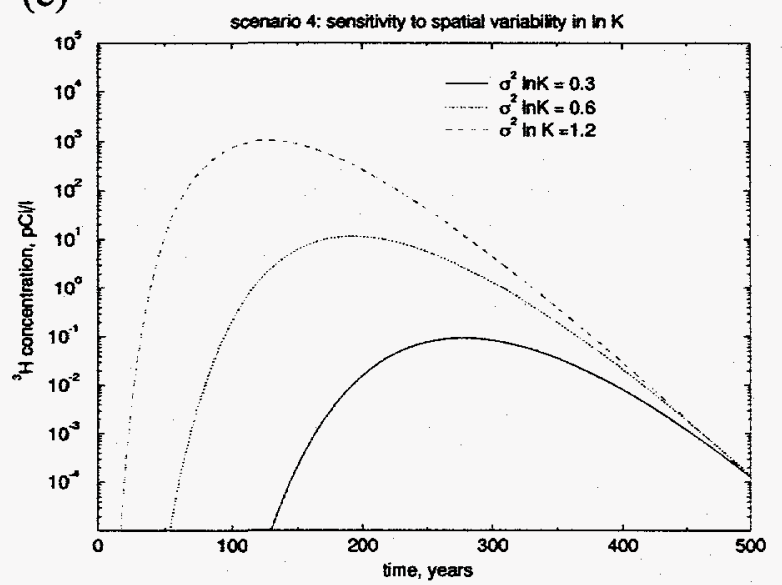

(b)

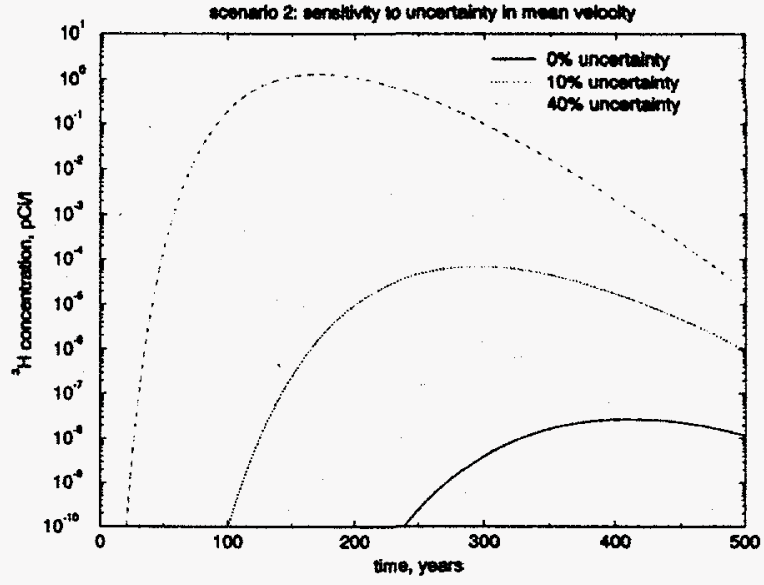

(d)

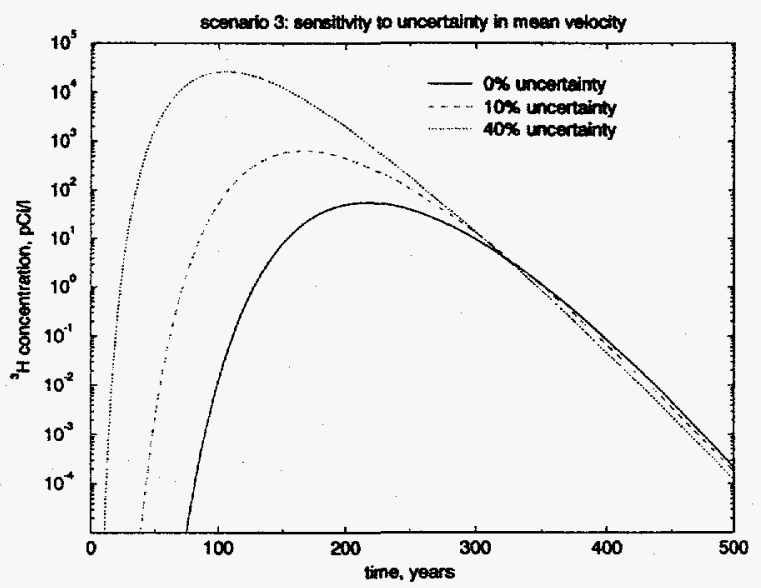

(f)

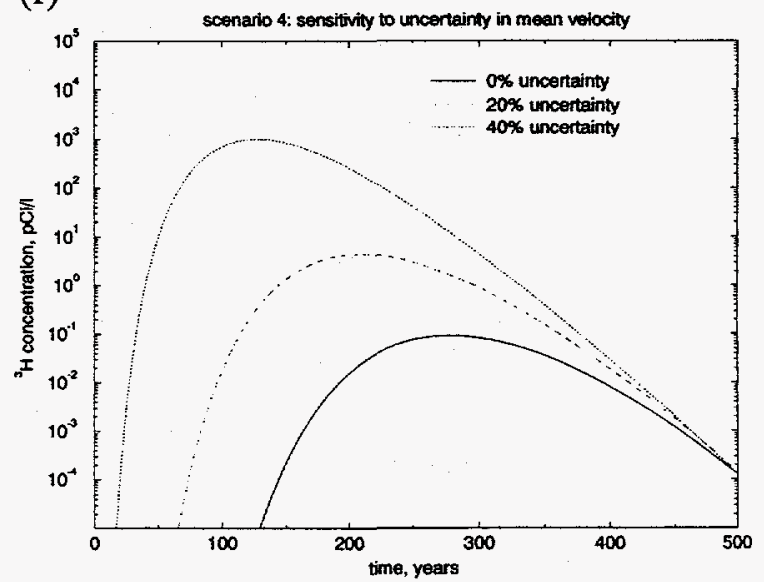




\section{DISTRIBUTION}

\section{Desert Research Institute}

Roger Jacobson

Desert Research Institute

Water Resources Center

P.O. Box 19040

Las Vegas, NV 89132-0040

Marjory Jones

Desert Research Institute

Water Resources Center

P.O. Box 60220

Reno, NV 89506-0220

\section{International Technology Corp.}

Richard M. Deshler

International Technology Corporation 4330 S. Valley View

Suite 114

Las Vegas, NV 89103-4047

Rick Waddell

Geotrans, c/o IT

4330 Valley View

Suite 112, MS-439

Las Vegas, NV 89103-4047

Joe Yeasted

International Technology Corporation

4330 S. Valley View

Suite 114

Las Vegas, NV 89103-4047

\section{Lawrence Livermore National Laboratory}

Lee Davisson

Nuclear Chemistry Division

Lawrence Livermore National Laboratory

P.O. Box 808

L-237

Livermore, CA 94550
Greg Nimz

Lawrence Livermore National Laboratory

P.O. Box 808

MS L233

Livermore, CA 94550

Los Alamos National Laboratory

Joe Thompson

Los Alamos National Laboratory

INC-11, MS J514

P.O. Box 1663

Los Alamos, NM 87545

Raytheon Services Nevada

Stuart E. Rawlinson

Raytheon Services Nevada

P.O. Box 95487, M/S 580

Las Vegas, NV 89193-5487

Reynolds Electrical \& Engineering Co.

Martha DeMarre

Chief, Document Research Section

Health Protection Dept.

Reynolds Electrical \& Engineering Co.

P.O. Box 98521

Las Vegas, NV 89193-8521

Brian Dozier

Reynolds Electrical \& Engineering Co.

2501 Wyandotte

Mercury, NV 89102

Sandia National Laboratories

David Gallegos

Sandia National Laboratories

Department 6331

P.O. Box 58.., M/S 1345

Albuquerque, NM 87185-1345

State of Nevada

Larry Franks

Nevada State Health Department

Radiological Health Section

620 Belrose Avenue

Las Vegas, NV 89158 


\section{U.S. Department of Defense}

David Bedsun

Defense Nuclear Agency

Field Command

Nevada Operations Office

P.O. Box 208

Mercury, NV 89023-0208

\section{U.S. Department of Energy}

Gylan Allen, Director

Test Operations Division

Nevada Operations Office

U.S. Department of Energy

P.O. Box 98518

Las Vegas, NV 89193-8518

Joanne M. Bradbery, Director

Contracts Division

Nevada Operations Office

U.S. Department of Energy

P.O. Box 98518

Las Vegas, NV 89193-8518

Kevin Cabble

Environmental Restoration Division

Nevada Operations Office

U.S. Department of Energy

P.O. Box 98518

Las Vegas, NV 89193-8518

Roxanne Danz

Environmental Restoration Division

Nevada Operations Office

U.S. Department of Energy

P.O. Box 98518

Las Vegas, NV 89193-8518

Doug Duncan

Hydrology Program Manager

Office of Environmental Restoration

and Waste Management

Nevada Operations Office

U.S. Department of Energy

P.O. Box 98518

Las Vegas, NV 89193-8518
Donald Elle, Director

Environmental Protection Division

Nevada Operations Office

U.S. Department of Energy

P.O. Box 98518

Las Vegas, NV 89193-8518

Joseph N. Fiore, Acting Assistant Manager

Office of Environmental Restoration

and Waste Management

Nevada Operations Office

U.S. Department of Energy

P.O. Box 98518

Las Vegas, NV 89193-8518

Joseph H. Kitchen

Project Control and Technology

Development Division

Nevada Operations Office

U.S. Department of Energy

P.O. Box 98518

Las Vegas, NV 89193-8518

Steve Lawrence

Environmental Restoration Division

Nevada Operations Office

U.S. Department of Energy

P.O. Box 98518

Las Vegas, NV 89193-8518

John S. Ledbetter

Contracts Division

Nevada Operations Office

U.S. Department of Energy

P.O. Box 98518 , MS 505

Las Vegas, NV 89193-8518

Kevin Leary

Environmental Restoration Division

Nevada Operations Office

U.S. Department of Energy

P.O. Box 98518

Las Vegas, NV 89193-8518

Steve Leedom

Test Operations Division

Nevada Operations Office

U.S. Department of Energy

P.O. Box 98518

Las Vegas, NV 89193-8518 
Steve Mellington, Director

Environmental Restoration Division

Nevada Operations Office

U.S. Department of Energy

P.O. Box 98518

Las Vegas, NV 89193-8518

Richard Pearl

Environmental Protection Division

Nevada Operations Office

U.S. Department of Energy

P.O. Box 98518

Las Vegas, NV 89193-8518

David S. Shafer

NV/Albuquerque Laboratories Division

Office of Southwestern Area Programs

U.S. Department of Energy

EM-452, Trevion II Bldg.

1000 Independence Ave., SW

Washington, D.C. 20585

\section{U.S. Environmental Protection Agency}

Deb Shaloud

Environmental Monitoring Systems Laboratory

Office of Radiation Protection

U.S. Environmental Protection Agency

P.O. Box 93478

Las Vegas, NV 89193-3478

\section{U.S. Geological Survey}

Virginia Glanzman

U.S. Geological Survey

Box 2506, MS 913

Denver Federal Center

Denver, CO 80225

Randy Laczniak

U.S. Geological Survey

Water Resources Division

6770 S. Paradise Rd.

Las Vegas, NV 89119
Paul Orkild

U.S. Geological Survey

Box 2506, MS 913

Denver Federal Center

Denver, CO 80225

Doug Trudeau

U.S. Geological Survey

Water Resources Division

6770 S. Paradise Rd.

Las Vegas, NV 89119

\section{LIBRARIES}

Annie Kelley

State Documents Department

Nevada State Library

Capitol Complex

Carson City, NV 89710

Archives

Getchell Library

University of Nevada, Reno

Beverly Carter

MacKay School of Mines Library

University of Nevada, Reno

Document Section, Library

University of Nevada, Las Vegas

4505 Maryland Parkway

Las Vegas, NV 89154

Library (Stead)

Desert Research Institute

P.O. Box 60220

Reno, Nevada 89506-0220

Library

IT Corporation

4330 S. Valley View

Suite 114

Las Vegas, NV 89103

ATTN: Toni Miller

Library

Southern Nevada Science Center

Desert Research Institute

P.O. Box 19040

Las Vegas, NV 89132-0040 
Technical Information Resource Center Nevada Operations Office

U.S. Department of Energy

P.O. Box 98518

Las Vegas, NV 89193-8518
Librarian

Water Resources Center Archives

$4100^{\prime}$ Brien Hall

University of California

Berkeley, CA 94720-1718 